\title{
Leptogorgins A-C, Humulane Sesquiterpenoids from the Vietnamese Gorgonian Leptogorgia sp.
}

\author{
Irina I. Kapustina ${ }^{1}$, Tatyana N. Makarieva ${ }^{1, *}$, Alla G. Guzii ${ }^{1}$, Anatoly I. Kalinovsky ${ }^{1}$, \\ Roman S. Popov ${ }^{1}$, Sergey A. Dyshlovoy ${ }^{1,2,3}{ }^{10}$, Boris B. Grebnev ${ }^{1}$, Gunhild von Amsberg ${ }^{2,3}$ and \\ Valentin A. Stonik ${ }^{1}$ \\ 1 G.B. Elyakov Pacific Institute of Bioorganic Chemistry, Far Eastern Branch of the Russian Academy of \\ Sciences, Pr. 100-let Vladivostoku 159, 690022 Vladivostok, Russia; ikapust@rambler.ru (I.I.K.); \\ gagry@rambler.ru (A.G.G.); kaaniv@piboc.dvo.ru (A.I.K.); prs_90@mail.ru (R.S.P.); \\ dyshlovoy@gmail.com (S.A.D.); grebnev_bor@mail.ru (B.B.G.); stonik@piboc.dvo.ru (V.A.S.) \\ 2 Department of Oncology, Hematology and Bone Marrow Transplantation with Section Pneumology, \\ Hubertus Wald-Tumorzentrum, University Medical Center Hamburg-Eppendorf, 20251 Hamburg, Germany; \\ g.von-amsberg@uke.de \\ 3 Martini-Klinik, Prostate Cancer Center, University Hospital Hamburg-Eppendorf, 20251 Hamburg, Germany \\ * Correspondence: makarieva@piboc.dvo.ru; Tel.: +7-950-295-66-25
}

Received: 26 May 2020; Accepted: 10 June 2020; Published: 13 June 2020

\begin{abstract}
Leptogorgins A-C (1-3), new humulane sesquiterpenoids, and leptogorgoid A (4), a new dihydroxyketosteroid, were isolated from the gorgonian Leptogorgia sp. collected from the South China Sea. The structures were established using MS and NMR data. The absolute configuration of $\mathbf{1}$ was confirmed by a modification of Mosher's method. Configurations of double bonds followed from NMR data, including NOE correlations. This is the first report of humulane-type sesquiterpenoids from marine invertebrates. Sesquiterpenoids leptogorgins A (1) and B (2) exhibited a moderate cytotoxicity and some selectivity against human drug-resistant prostate cancer cells 22Rv1.
\end{abstract}

Keywords: gorgonian; Leptogorgia; humulane sesquiterpenoids; anticancer activity

\section{Introduction}

Marine gorgonian corals have been reported to be a rich source of isoprenoids with unprecedented chemical structures and biological activities [1]. Species of the genus Leptogorgia (Gorgoniidae) have been shown to produce cembranoids [2-7], polyoxygenated steroids [8-12], alkaloids [13], fatty acids [14], homarine [15], thyroxine, and vitamin D [16]. To date, different humulane-type sesquiterpenoids have been found in plants [17-19], liverworts [20], and fungi [21-23]. However, until recently they were not found in marine invertebrates, including gorgonians. Interestingly, two new norhumulene were isolated from the soft coral Sinularia hirta [24]. In addition, one more norhumulene was found in a formazan soft coral Sinularia gibberosa [25]. Humulanes from the peeled stems of Syringa pinnatifida inhibit NO production in LPS-induced RAW264.7 macrophage cells and decrease the TNF- $\alpha$ and IL-6 levels in RAW264.7 cells [26]. Additionally, plant cytochrome P450 was reported to catalyse the conversion of $\alpha$-humulene into 8-hydroxy- $\alpha$-humulene [27].

For some humulenes, an antitumor activity was reported. Thus, zurumbone (2,6,9-humulatriene-8-one), as an active component of the Zingiber aromaticum extract, was shown to be active in human cancer HT-29, CaCO-2, and NCF-7 cell lines. Remarkably, it was more active than curcumin, which was used as a reference compound [28]. Herein, we report the structures and biological activities of three new humulane sesquiterpenoids, leptogorgins A-C (1-3), and a new steroid, leptogorgoid A (4), from the gorgonian Leptogorgia sp. (Figure 1). 

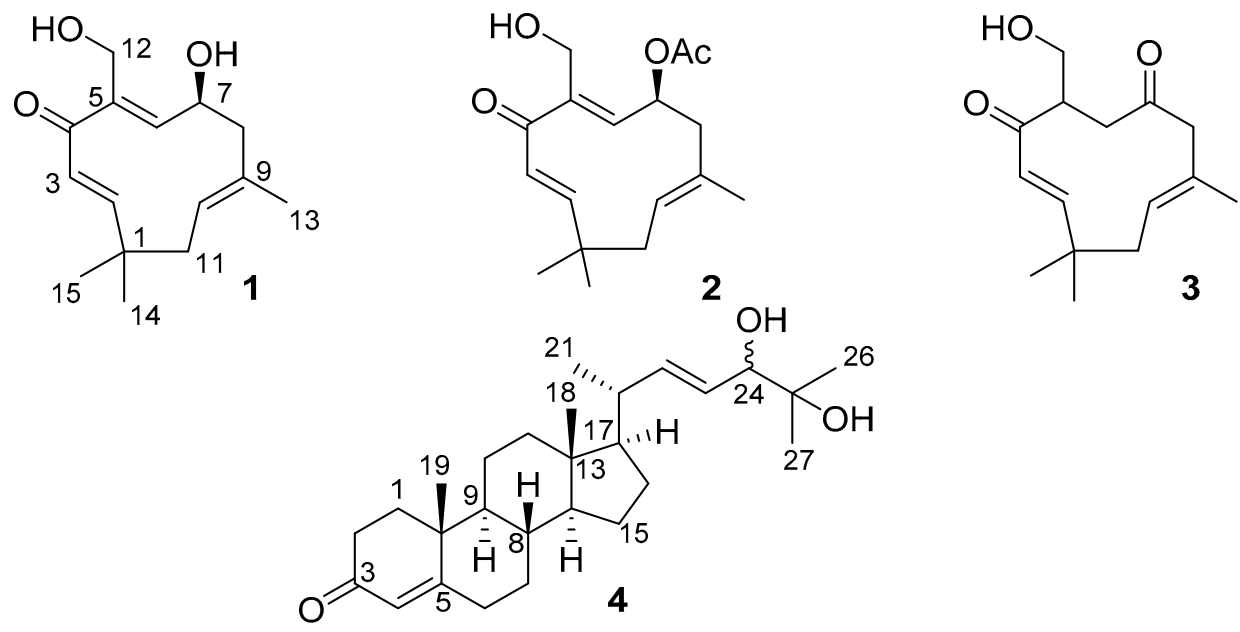

3

Figure 1. The structures of 1-4.

\section{Results and Discussion}

The EtOH extract of the gorgonian Leptogorgia sp. (registration number O38-011) was concentrated and partitioned between aqueous $\mathrm{EtOH}$ and $n$-hexane. The EtOH-soluble materials were separated by silica gel flash chromatography, followed by Sephadex LH-20 column chromatography and normal and reversed-phase HPLC to give leptogorgins A-C (1-3, 2.5, 0.8, and $1.0 \mathrm{mg}$, respectively) and leptogorgoid A (4, $0.6 \mathrm{mg})$.

Compound $\mathbf{1}$ was isolated as a colourless oil. The HRESIMS of $\mathbf{1}$ showed an $[\mathrm{M}+\mathrm{Na}]^{+}$ion peak at $m / z 273.1459$ and an $[\mathrm{M}-\mathrm{H}]^{-}$ion peak at $\mathrm{m} / \mathrm{z} 249.1498$, which indicated a molecular formula of $\mathrm{C}_{15} \mathrm{H}_{22} \mathrm{O}_{3}$. The ${ }^{13} \mathrm{C}$ NMR spectrum displayed 15 signals, which could be assigned to a sesquiterpene substructure. Analysis of the ${ }^{1} \mathrm{H},{ }^{13} \mathrm{C}$, and HSQC NMR spectra (Table 1) revealed signals indicative of one ketocarbonyl $\left(\delta_{C} 200.8, C-4\right)$, one oxymethine $\left(\delta_{H} 4.21 / \delta_{C} 71.7, C-7\right)$, one oxymethylene $\left(\delta_{H} 4.25\right.$; $\left.4.38 / \delta_{\mathrm{C}} 64.7, \mathrm{C}-12\right)$, four methines $\left(\delta_{\mathrm{H}} 6.32 / \delta_{\mathrm{C}} 164.8, \mathrm{C}-2 ; \delta_{\mathrm{H}} 5.97 / \delta_{\mathrm{C}} 128.1, \mathrm{C}-3 ; \delta_{\mathrm{H}} 5.75 / \delta_{\mathrm{C}} 133.8, \mathrm{C}-6\right.$, and $\left.\delta_{\mathrm{H}} 5.22 / \delta_{\mathrm{C}} 125.9, \mathrm{C}-10\right)$, two quaternary $\left(\delta_{\mathrm{C}} 143.0, \mathrm{C}-5 ; \delta_{\mathrm{C}} 132.4, \mathrm{C}-9\right)$ olefinic carbons, and two methylene groups $\left(\delta_{\mathrm{H}} 1.96\right.$ and $2.68 / \delta_{\mathrm{C}} 45.3, \mathrm{C}-8 ; \delta_{\mathrm{H}} 1.95$ and $\left.2.40 / \delta_{\mathrm{C}} 40.7, \mathrm{C}-11\right)$, as well as one quaternary carbon $\left(\delta_{\mathrm{C}} 38.0, \mathrm{C}-1\right)$, one corresponding vinylic methyl $\left(\delta_{\mathrm{H}} 1.72 / \delta_{\mathrm{C}} 20.1, \mathrm{CH}_{3}-13\right)$ and two methyl singlets $\left(\delta_{\mathrm{H}} 1.18 / \delta_{\mathrm{C}} 24.0, \mathrm{CH}_{3}-14 ; \delta_{\mathrm{H}} 1.13 / \delta_{\mathrm{C}} 29.1, \mathrm{CH}_{3}-15\right)$. The ${ }^{1} \mathrm{H}-{ }^{1} \mathrm{H}$ COSY spectrum enabled three structural fragments to be established: $\mathrm{CH}=\mathrm{CH}-,-\mathrm{CH}-\mathrm{CH}-\mathrm{CH}_{2-}^{-}$, and $-\mathrm{CH}-\mathrm{CH}_{2-}$, which could be connected by observing the correlations in the HMBC experiment (Figure 2). Thus, HMBC correlations from $\mathrm{H}-3$ to C-1, C-4, and C-5, from H-6 to C-12 and C-8, from H-7 to C-5 and C-8, from H-8 to C-7, C-9, $\mathrm{C}-10$, and $\mathrm{C}-13$, from $\mathrm{H}-11$ to $\mathrm{C}-10, \mathrm{C}-9$, and $\mathrm{C}-1$, and from $\mathrm{CH}_{3}-14$ and $\mathrm{CH}_{3}-15$ to $\mathrm{C}-1, \mathrm{C}-2$, and $\mathrm{C}-11$ established the planar structure of $\mathbf{1}$ (Figure 2).

The geometry of the $\Delta^{2,3}$ double bond was further determined to be $E$ by considering the coupling constant $(J=16.3 \mathrm{~Hz})$ displayed in its ${ }^{1} \mathrm{H}$ NMR spectrum. The NOE correlations of $\mathrm{CH}_{3}-13$ to $\mathrm{H}-2, \mathrm{H}-6$, and $\mathrm{CH}_{2}-11$, as well as H-10 with H-6 and H-6 with H-2 (Figure 3), suggested that the $\Delta^{5(6)}$ and $\Delta^{9(10)}$ double bonds in $\mathbf{1}$ were $E$ configured.

A modified Mosher ester analysis was obtained, and the negative $\Delta \delta^{\mathrm{SR}}\left(\delta^{\mathrm{S}}-\delta^{\mathrm{R}}\right)$ values of Ha- 8 , $\left(\Delta \delta_{\mathrm{H}}-0.01\right), \mathrm{Hb}-8,\left(\Delta \delta_{\mathrm{H}}-0.05\right)$ and $\mathrm{CH}_{3}-13\left(\Delta \delta_{\mathrm{H}}-0.01\right)$, and positive $\Delta \delta^{\mathrm{SR}}$ values of $\mathrm{H}-6\left(\Delta \delta_{\mathrm{H}}+0.04\right)$ Ha-12 $\left(\Delta \delta_{\mathrm{H}}+0.01\right)$, and $\mathrm{Hb}-12\left(\Delta \delta_{\mathrm{H}}+0.04\right)$ (Figure 4) revealed the $7 S$ configuration [25]. Thus, the structure of 1 was determined as 4-oxohumula-2E,5E,9E-trien-7S,12-diol, as shown in Figure 1, and named leptogorgin A (1). 
Table 1. ${ }^{1} \mathrm{H}(700 \mathrm{MHz})$ and ${ }^{13} \mathrm{C}(175 \mathrm{MHz}) \mathrm{NMR}$ spectroscopic data for $\mathbf{1}, 2$ and 3 in $\mathrm{CDCl}_{3}$.

\begin{tabular}{|c|c|c|c|c|c|c|}
\hline \multirow{2}{*}{ Position } & \multicolumn{2}{|r|}{1} & \multicolumn{2}{|c|}{2} & \multicolumn{2}{|r|}{3} \\
\hline & $\delta_{C}$ & $\delta_{\mathrm{H}}$ mult $(J$ in $\mathrm{Hz})$ & $\delta_{\mathrm{C}}$ & $\delta_{\mathrm{H}}$ mult $(J$ in $\mathrm{Hz})$ & $\delta_{C}$ & $\delta_{\mathrm{H}}$ mult $(J$ in $\mathrm{Hz})$ \\
\hline 1 & $38.0 \mathrm{C}$ & - & $38.1 \mathrm{C}$ & - & $40.4 * \mathrm{C}$ & - \\
\hline 2 & $164.8 \mathrm{CH}$ & $\begin{array}{l}6.32, \mathrm{~d} \\
(16.3)\end{array}$ & $162.8 \mathrm{CH}$ & $\begin{array}{l}6.24, \mathrm{~d} \\
(16.3)\end{array}$ & $152.7 \mathrm{CH}$ & $\begin{array}{l}6.29, \mathrm{~d} \\
(16.1)\end{array}$ \\
\hline 3 & $128.1 \mathrm{CH}$ & $\begin{array}{l}5.97, \mathrm{~d} \\
(16.3)\end{array}$ & $128.1 \mathrm{CH}$ & $\begin{array}{l}6.07, d \\
(16.3)\end{array}$ & $128.4 \mathrm{CH}$ & $\begin{array}{c}5.76, d \\
(16.1)\end{array}$ \\
\hline 4 & $200.8 \mathrm{C}$ & - & $199.4 \mathrm{C}$ & - & $204.3 C$ & - \\
\hline 5 & $143.0 \mathrm{C}$ & - & $145.2 \mathrm{C}$ & & $48.6 \mathrm{CH}$ & $3.38, \mathrm{~m}$ \\
\hline 6 & $133.8 \mathrm{CH}$ & $\begin{array}{l}5.75, \mathrm{~d} \\
(10.6)\end{array}$ & $129.5 \mathrm{C}$ & $\begin{array}{c}5.70, \mathrm{dt} \\
(10.6 ; 1.3)\end{array}$ & $41.2 \mathrm{CH}_{2}$ & $\begin{array}{c}2.43, \mathrm{dd} \\
(16.9 ; 2.9) \\
2.73, \mathrm{dd} \\
(16.9 ; 9.7)\end{array}$ \\
\hline 7 & $71.7 \mathrm{CH}$ & $\begin{array}{c}4.21 \mathrm{td} \\
(10.6 ; 5.4)\end{array}$ & $72.9 \mathrm{CH}$ & $\begin{array}{c}5.28, \mathrm{td} \\
(10.6 ; 5.1)\end{array}$ & $204.3 \mathrm{C}$ & \\
\hline 8 & $45.3 \mathrm{CH}_{2}$ & $1.96, \mathrm{~m}$ & $42.7 \mathrm{CH}_{2}$ & $2.03, \mathrm{~m}$ & $54.1 \mathrm{CH}_{2}$ & $\begin{array}{l}3.00, \mathrm{~d} \\
(12.4)\end{array}$ \\
\hline & & $\begin{array}{c}2.68, \mathrm{dd} \\
(12.2 ; 5.4)\end{array}$ & & $\begin{array}{c}2.69, \mathrm{dd} \\
(12.5 ; 5.1)\end{array}$ & & $\begin{array}{c}3.15, \mathrm{~d} \\
(12.4)\end{array}$ \\
\hline 9 & $132.4 \mathrm{C}$ & - & $128.1 \mathrm{C}$ & - & $127.8 \mathrm{C}$ & - \\
\hline 10 & $125.9 \mathrm{CH}$ & $\begin{array}{c}5.22, \mathrm{brd} \\
(12.5)\end{array}$ & $127.1 \mathrm{C}$ & $5.32, \mathrm{~m}$ & $129.0 \mathrm{CH}$ & $\begin{array}{c}5.37, \mathrm{ddd} \\
(10.5 ; 5.7,1.2)\end{array}$ \\
\hline 11 & $40.7 \mathrm{CH}_{2}$ & $\begin{array}{c}1.95, \mathrm{~m} \\
2.40, \mathrm{t} \\
(12.5)\end{array}$ & 40.7 & $\begin{array}{c}1.97, \mathrm{~m} \\
2.39, \mathrm{t} \\
(12.6)\end{array}$ & $40.2 * \mathrm{CH}_{2}$ & $\begin{array}{l}2.00, \mathrm{~m} \\
2.07, \mathrm{~m}\end{array}$ \\
\hline 12 & $64.7 \mathrm{CH}_{2}$ & $\begin{array}{l}4.25, \mathrm{~d} \\
(13.3) \\
4.38, \mathrm{~d} \\
(13.3)\end{array}$ & $64.8 \mathrm{CH}_{2}$ & $\begin{array}{c}4.26, \mathrm{dd} \\
(13.2 ; 4.6) \\
4.40, \mathrm{dd} \\
(13.2 ; 6.3)\end{array}$ & $63.0 \mathrm{CH}_{2}$ & $\begin{array}{l}3.78, \mathrm{~m} \\
3.89, \mathrm{~m}\end{array}$ \\
\hline 13 & $20.1 \mathrm{CH}_{3}$ & $1.72, \mathrm{~s}$ & $20.0 \mathrm{CH}_{3}$ & $1.73, \mathrm{~s}$ & $19.0 \mathrm{CH}_{3}$ & $1.64, \mathrm{~s}$ \\
\hline 14 & $24.0 \mathrm{CH}_{3}$ & $1.18, \mathrm{~s}$ & $23.9 \mathrm{CH}_{3}$ & $1.21, \mathrm{~s}$ & $28.8 \mathrm{CH}_{3}$ & $1.21, \mathrm{~s}$ \\
\hline 15 & $29.1 \mathrm{CH}_{3}$ & $1.13, \mathrm{~s}$ & $29.2 \mathrm{CH}_{3}$ & $1.13, \mathrm{~s}$ & $24.3 \mathrm{CH}_{3}$ & $1.09, \mathrm{~s}$ \\
\hline $\mathrm{COCH}_{3}$ & & & $169.7 \mathrm{C}$ & - & & \\
\hline $\mathrm{COCH}_{3}$ & & & $21.2 \mathrm{CH}_{3}$ & $1.98, \mathrm{~s}$ & & \\
\hline
\end{tabular}

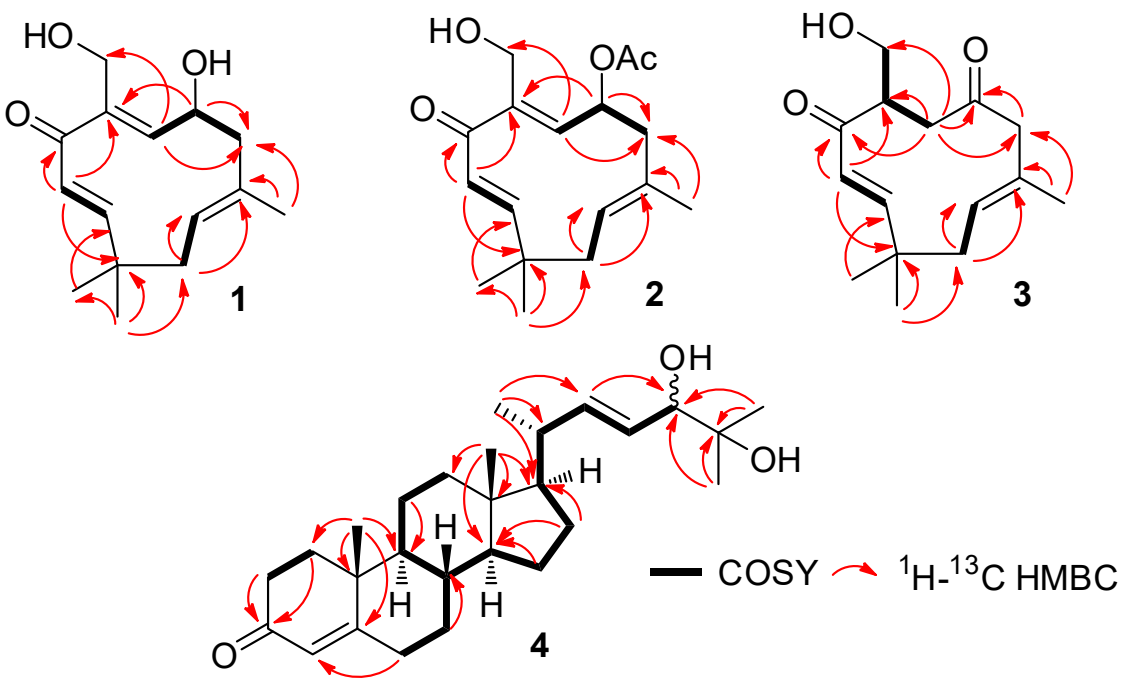

Figure 2. Selected COSY and HMBC correlations for 1-4. 


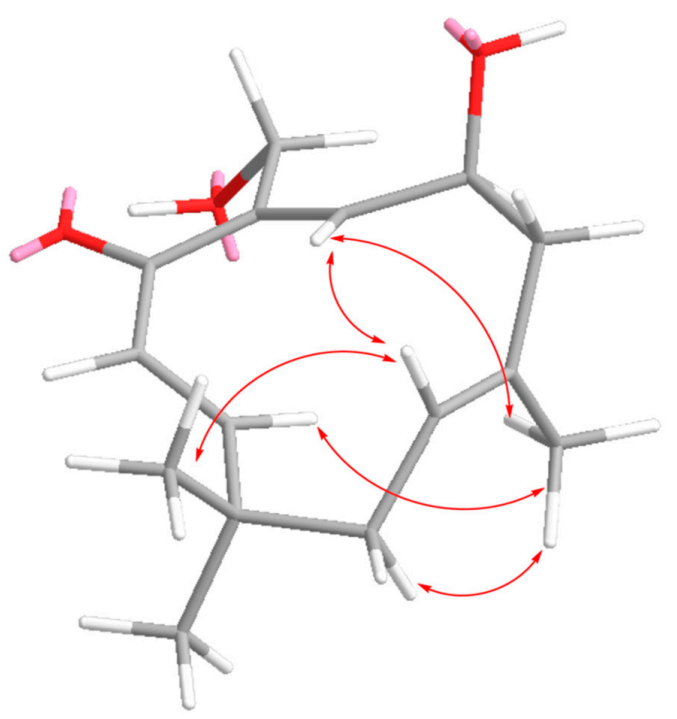

Figure 3. Key NOE correlations for $\mathbf{1}$.

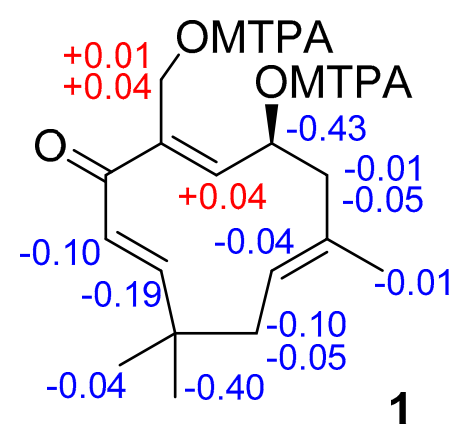

Figure 4. $\Delta \delta\left(\delta^{S}-\delta^{R}\right)$ values (in ppm, $\left.\mathrm{CDCl}_{3}\right)$ for the MTPA esters of $\mathbf{1}$.

Compound 2 was obtained as a colourless oil. The HRESIMS of 2 showed an $[\mathrm{M}+\mathrm{Na}]^{+}$ion peak at $m / z 315.1567$ and an $[\mathrm{M}-\mathrm{H}]^{-}$ion peak at $\mathrm{m} / \mathrm{z} 291.1602$, which indicated a molecular formula of $\mathrm{C}_{17} \mathrm{H}_{24} \mathrm{O}_{4}$. The ${ }^{1} \mathrm{H}$ and ${ }^{13} \mathrm{C}$ NMR spectra of $\mathbf{2}$ (Table 1) were similar to those of $\mathbf{1}$, suggesting that this compound possessed the same humulane skeleton. The key differences were in $\delta_{\mathrm{H}}$ for $\mathrm{H}-7$ and $\delta_{C}$ for carbon 7 in the spectrum of $2\left(\delta_{H} 5.28 / \delta_{C} 72.9\right)$. The corresponding signals were shifted downfield, compared to those of $\mathbf{1}\left(\delta_{\mathrm{H}} 4.21 / \delta_{\mathrm{C}} 71.7\right)$. This characteristic difference and HRESIMS data were caused by the hydroxy group in $\mathbf{1}$ being displaced by an acetoxyl group in $\mathbf{2}$. The HMBC spectra of 2 demonstrated the expected key correlations. The ECD spectrum of compound 2 was compared with the ECD spectrum of leptogorgin A (1), in which the corresponding absolute configuration was established by modification of Mosher's method. Both ECD spectra displayed similar Cotton effects (see Figure S27), allowing us to establish the same 7S configuration for compound 2. From these data, compound 2 was determined to be 4-oxohumula-2E,5E,9E-trien-7S-acetate,12-ol, as shown in Figure 1, and named leptogorgin B (2).

Compound $\mathbf{3}$ was isolated as a colourless oil. The HRESIMS of $\mathbf{1}$ showed an $[\mathrm{M}+\mathrm{Na}]^{+}$ion peak at $m / z 273.1459$ and an $[\mathrm{M}-\mathrm{H}]^{-}$ion peak at $m / z 249.1496$, which indicated a molecular formula of $\mathrm{C}_{15} \mathrm{H}_{22} \mathrm{O}_{3}$. The ${ }^{1} \mathrm{H}$ and ${ }^{13} \mathrm{C}$ NMR spectra (Table 1 ) of $\mathbf{3}$ were similar to those of $\mathbf{1}$ and $\mathbf{2}$, suggesting that this compound also possessed the same humulane skeleton. Key differences concerned $\delta_{\mathrm{H}}$ for protons 6,7 , and 8 and $\delta_{C}$ for carbons $4,5,6,7$, and 8 in the spectrum of 3 , which were different compared to those of $\mathbf{1}$ and 2. This characteristic difference was caused by an absence of the hydroxy group, as in $\mathbf{1}$, or acetyl, as in 2 at position 7, being displaced by a ketogroup in 3, as well as by the absence of the 5,6 double bound in 3 . The location of the ketogroup was further determined to be at C-7 by COSY, HSQC, 
and HMBC experiments. Thus, compound 3 was determined to be 4,7-dioxohumula-2E,9E-dien-12-ol, as shown in Figure 1, and named leptogorgin C (3).

Compound 4 was isolated as a colourless powder. The HRESIMS of 4 showed an $[\mathrm{M}+\mathrm{Na}]^{+}$ ion peak at $m / z 437.3026$ and an $[\mathrm{M}-\mathrm{H}]^{-}$ion peak at $\mathrm{m} / \mathrm{z} 413.3061$, which indicated a molecular formula of $\mathrm{C}_{27} \mathrm{H}_{42} \mathrm{O}_{3}$. The data of 1D- and 2D-NMR spectra of $\mathbf{1}$ (Table 2) indicated that this compound belonged to steroids. Its spectra contained five methyl groups, including two angular methyl groups in the steroid nucleus $\left(\delta_{\mathrm{H}} 0.74 / \delta_{\mathrm{C}} 12.2, \delta_{\mathrm{H}} 1.19 / \delta_{\mathrm{C}} 17.4\right)$ and three methyl groups of the side chain $\left(\delta_{\mathrm{H}} 1.04 / \delta_{\mathrm{C}} 20.3, \delta_{\mathrm{H}} 1.15 / \delta_{\mathrm{C}} 23.8\right.$, and $\left.\delta_{\mathrm{H}} 1.20 / \delta_{\mathrm{C}} 26.4\right)$, eight methylene groups, six methine groups, including one oxygenated methine $\left(\delta_{\mathrm{H}} 3.85 / \delta_{\mathrm{C}} 79.7\right)$, two quaternary sp ${ }^{3}$ carbons $\left(\delta_{\mathrm{C}} 38.6, \delta_{\mathrm{C}} 42.5\right)$, one quaternary sp $\mathrm{sp}^{3}$ oxygenated carbon $\left(\delta_{\mathrm{C}} 72.8\right)$, one trisubstituted double bond $\left(\delta_{\mathrm{H}} 5.72 / \delta_{\mathrm{C}} 123.8\right.$ and 171.4), one disubstituted double bond $\left(\delta_{\mathrm{H}} 5.61 / \delta_{\mathrm{C}} 140.8\right.$ and $\left.\delta_{\mathrm{H}} 5.43 / \delta_{\mathrm{C}} 126.0\right)$, and one conjugated with double bond ketone carbonyl $\left(\delta_{C}\right.$ 199.5). The geometry of the 22,23 double bond was further determined to be $E$ by considering the coupling constant $(J=15.3 \mathrm{~Hz})$ displayed in its ${ }^{1} \mathrm{H}$ NMR spectrum. The HMBC spectra of 4 demonstrated the expected key correlations. From these data, compound 4 was determined to be 3-oxocholesta-4E,22E-diene-24,25 dienol, as shown in Figure 1, and named leptogorgoid A (4).

Table 2. ${ }^{1} \mathrm{H}(700 \mathrm{MHz})$ and ${ }^{13} \mathrm{C}(175 \mathrm{MHz})$ NMR spectroscopic data for 4 in $\mathrm{CDCl}_{3}$.

\begin{tabular}{|c|c|c|c|c|c|}
\hline Position & $\delta_{C}$ & $\delta_{H}$ mult $(J$ in $\mathrm{Hz})$ & Position & $\delta_{C}$ & $\delta_{\mathrm{H}}$ mult $(J$ in $\mathrm{Hz})$ \\
\hline 1 & $35.7 \mathrm{CH}_{2}$ & $\begin{array}{l}1.70, \mathrm{~m} \\
2.03, \mathrm{~m}\end{array}$ & 16 & $28.5 \mathrm{CH}_{2}$ & $\begin{array}{l}1.29, \mathrm{~m} \\
1.70, \mathrm{~m}\end{array}$ \\
\hline 2 & $34.0 \mathrm{CH}_{2}$ & $\begin{array}{l}2.34, \mathrm{~m} \\
2.42, \mathrm{~m}\end{array}$ & 17 & $55.6 \mathrm{CH}$ & $1.19, \mathrm{~m}$ \\
\hline 3 & 199.5 & - & 18 & $12.2 \mathrm{CH}_{3}$ & $0.74, \mathrm{~s}$ \\
\hline 4 & $123.8 \mathrm{CH}$ & $5.72 \mathrm{~s}$ & 19 & $17.4 \mathrm{CH}_{3}$ & $1.19, \mathrm{~s}$ \\
\hline 5 & $171.4 \mathrm{C}$ & - & 20 & $39.8 \mathrm{CH}$ & $2.14, \mathrm{~m}$ \\
\hline 6 & $32.9 \mathrm{CH}_{2}$ & $\begin{array}{l}2.27, \text { ddd }(14.7 ; 4.1 ; 2.4) \\
2.40, \mathrm{~m}\end{array}$ & 21 & $20.3 \mathrm{CH}_{3}$ & $1.04, \mathrm{~d}(6.6)$ \\
\hline 7 & $32.0 \mathrm{CH}_{2}$ & $\begin{array}{l}1.02, \mathrm{~m} \\
1.84, \mathrm{~m}\end{array}$ & 22 & $140.8 \mathrm{CH}$ & $5.61, \mathrm{dd}(8.6 ; 15.3)$ \\
\hline 8 & $35.7 \mathrm{CH}$ & $1.53, \mathrm{~m}$ & 23 & $126.0 \mathrm{CH}$ & $5.43, \mathrm{dd}(7.3 ; 15.3)$ \\
\hline 9 & $53.8 \mathrm{CH}$ & $0.94, \mathrm{~m}$ & 24 & $79.7 \mathrm{CH}$ & $3.84, \mathrm{~d}(7.3)$ \\
\hline 10 & $38.6 \mathrm{C}$ & - & 25 & $72.8 \mathrm{C}$ & - \\
\hline 11 & $21.0 \mathrm{CH}_{2}$ & $\begin{array}{c}1.44, \text { ddd }(13.6 ; 17.1 ; 4.2) \\
1.54, \mathrm{~m}\end{array}$ & 26 & $23.8 \mathrm{CH}_{3}$ & $1.15, \mathrm{~s}$ \\
\hline 12 & $39.5 \mathrm{CH}_{2}$ & $\begin{array}{l}1.20, \mathrm{~m} \\
2.01, \mathrm{~m}\end{array}$ & 27 & $26.4 \mathrm{CH}_{3}$ & $1.20, \mathrm{~s}$ \\
\hline 13 & $42.5 \mathrm{C}$ & - & & & \\
\hline 14 & $55.8 \mathrm{CH}$ & $1.04, \mathrm{~m}$ & & & \\
\hline 15 & $24.2 \mathrm{CH}_{2}$ & $1.11, \mathrm{~m}$ & & & \\
\hline & & $1.60, \mathrm{~m}$ & & & \\
\hline
\end{tabular}

Next, we investigated the effects of the leptogorgins A (1) and B (2) on the viability of 22Rv1 cells (human drug-resistant prostate cancer cells) as well as on PNT2 cells (human prostate non-cancer cells). MTT assay revealed 1 to exhibit a moderate cytotoxicity to both cell lines $\left(\mathrm{IC}_{50}=31.0 \mu \mathrm{M}\right.$ and $35.8 \mu \mathrm{M}$, respectively), whereas 2 had $\mathrm{IC}_{50}>100 \mu \mathrm{M}$. Doxorubicine was used as a positive control and exhibited in 22Rv1 and PNT2 cells IC 50 of $0.084 \mu \mathrm{M}$ and $1.12 \mu \mathrm{M}$, respectively. Interestingly, both compounds were more active in human cancer 22Rv1 cells, in comparison with PNT2 cells (Figure 5). Additionally, we examined the ability of these compounds to inhibit the colony formation of 22Rv1 prostate cancer cells; however, no significant inhibitory activity was observed under the treatment with cytotoxic or 
non-cytotoxic concentrations of the compounds up to a concentration of $100 \mu \mathrm{M}$ (data not shown). The isolated compounds may be considered as prototypes for future anticancer agents capable of selective inhibition of human drug-resistant prostate cancer cells. Note that we could not isolate enough leptogorgins C (3) and leptogorgoid A (4) to investigate the biological activity of these compounds.

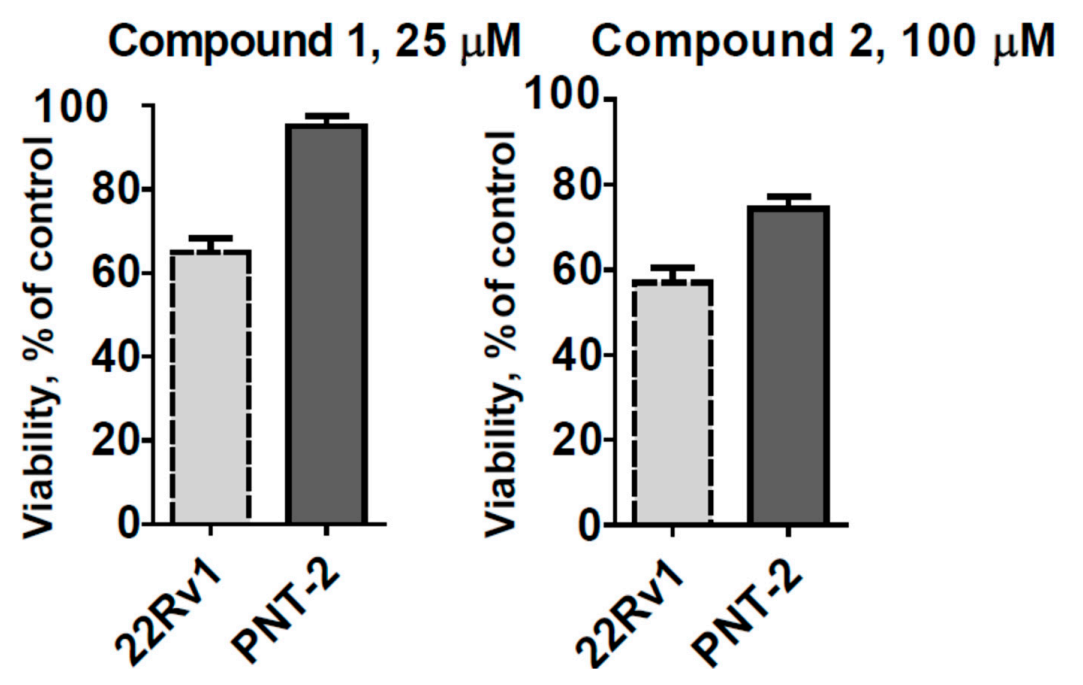

Figure 5. The viability of 22Rv1 and PNT2 cells after $72 \mathrm{~h}$ of treatment with the indicated concentrations of the investigated compounds. The viability was evaluated using MTT assay.

\section{Materials and Methods}

\subsection{General Procedures}

Optical rotation was measured using a PerkinElmer 343 polarimeter. UV spectra were recorded on a Shimadzu UV-1601 PC spectrophotometer. ECD spectra were recorded with an Applied Photophysics Chirascan plus spectropolarimeter. IR spectroscopic data were measured using an IR spectrometer Equinox 55 (Bruker, Ettlingen, Germany) in $\mathrm{CHCl}_{3}$. The ${ }^{1} \mathrm{H}$ and ${ }^{13} \mathrm{C} \mathrm{NMR}$ spectra were recorded on a Bruker Avance III-700 spectrometer (Bruker, Ettlingen, Germany) at 700 and $175 \mathrm{MHz}$, respectively, with $\mathrm{Me}_{4} \mathrm{Si}$ as an internal standard. ESI mass spectra (including HRESIMS) were obtained on a Bruker maXis Impact II Q-TOF mass spectrometer (Bruker Daltonics, Bremen, Germany) by direct infusion in $\mathrm{MeOH}$. Low-pressure column liquid chromatography was performed using silica gel (Sigma-Aldrich Co., St. Louis, MO, USA) and Sephadex LH-20 (Sigma, Chemical Co., St. Louis, MO, USA) columns. HPLC was performed using a Shimadzu Instrument equipped with the differential refractometer RID-10A, a YMC-Pack ODS-A $(250 \times 10 \mathrm{~mm})$ column (YM Co., Ltd., Kyoto, Japan), and a silica gel column (SUPELCOSIL ${ }^{\mathrm{TM}}, 250 \times 10 \mathrm{~mm}, 5 \mu \mathrm{m}$ ) (Sigma-Aldrich Co., USA). TLC was performed on silica gel plates $(5-17 \mu \mathrm{m}$, Sorbfil, Russia).

\subsection{Animal Material}

The gorgonian Leptogorgia sp. (registration number PIBOC O38-011) was collected by dredging during the 38th scientific cruise of R/V "Academic Oparin", May 2010, South China sea (09 $08^{\prime} 2^{\prime \prime}$ N; $109^{\circ} 01^{\prime} 7^{\prime \prime}$ E, depth $134 \mathrm{~m}$ ), in Vietnamese waters. A voucher specimen of 038-011 sample is stored in the Marine invertebrate collection of the G.B. Elyakov Pacific Institute of Bioorganic Chemistry FEB RAS (Vladivostok, Russia).

\subsection{Extraction and Isolation}

The EtOH extract of the gorgonian (dry weight $170 \mathrm{~g}$ ) was concentrated and partitioned between $n$-hexane and aqueous EtOH. The EtOH-soluble material was subjected to column chromatography on a silica gel column using $\mathrm{CHCl}_{3}-\mathrm{EtOH}$ (stepwise gradient, 1:0 1:1). Fractions eluted with $\mathrm{CHCl}_{3}: \mathrm{EtOH}$ 
(20:1) were concentrated and residue (171.3 $\mathrm{mg}$ ) was subjected to column chromatography on a LH-20 column using $\mathrm{CHCl}_{3}: \mathrm{EtOH}, 2: 1$ to yield two fractions: F1 $(46.6 \mathrm{mg}$ ) and F2 (61.4 mg). Preparative HPLC of the fraction F1 (SUPELCOSIL, $n$-hexane:EtOAc, 1:1) gave pure leptogorgin A (1, 2.5 mg, $0.002 \%$ based on dry weight of gorgonian). Preparative HPLC of the fraction F2 (YMC-Parck ODS-A, EtOH: $\mathrm{H}_{2} \mathrm{O}$, 3:2) gave three sub-fractions: F2-1 $(2.5 \mathrm{mg})$, F2-2 $(6.4 \mathrm{mg})$, and F2-3 $(8.0 \mathrm{mg})$. Preparative HPLC of the fraction F2-1 (SUPELCOSIL, $n$-hexane:EtOAc, 2:3) gave pure leptogorgin C $(3,1.0 \mathrm{mg}, 0.001 \%$ based on dry weight of gorgonian). Preparative HPLC of the fraction F2-2 (SUPELCOSIL, $n$-hexane:EtOAc, 1:1) gave pure leptogorgin $\mathrm{B}(\mathbf{2}, 0.8 \mathrm{mg}, 0.001 \%$ based on dry weight of gorgonian). Preparative HPLC of the fraction F2-3 (SUPELCOSIL, $n$-hexane:EtOAc, 1:1) gave pure leptogorgoid A $(4,0.6 \mathrm{mg}, 0.0006 \%$ based on dry weight of gorgonian).

\subsection{Compound Characterization Data}

Leptogorgin A (1): colourless oil; $[\alpha]_{\mathrm{D}}^{22}+38.7\left(c 0.2, \mathrm{CHCl}_{3}\right)$; UV (EtOH) $\lambda_{\max }(\log \varepsilon) 195$ (4.05), 229 (3.75) nm; ECD $\left(c 1 \times 10^{-3} \mathrm{M}, \mathrm{EtOH}\right) \lambda_{\max }(\Delta \varepsilon) 194$ (7.56), 228 (9.41), $274(-3.52), 333$ (1.30) nm; IR $\left(\mathrm{CHCl}_{3}\right): v_{\max } 3604,2964,2928,2860,1723,1641,1458,1387,1365,1261,1243,1104,1012 \mathrm{~cm}^{-1}$; ${ }^{1} \mathrm{H}$ and ${ }^{13} \mathrm{C}$ NMR data $\left(\mathrm{CDCl}_{3}\right)$, Table 1; HRESIMS $\mathrm{m} / \mathrm{z} 273.1459[\mathrm{M}+\mathrm{Na}]^{+}$(calcd for $\mathrm{C}_{15} \mathrm{H}_{22} \mathrm{O}_{3} \mathrm{Na}$, 273.1461); HRESIMS $m / z 249.1498$ [M - H] $]^{-}$(calcd for $\mathrm{C}_{15} \mathrm{H}_{21} \mathrm{O}_{3}$ 249.1496).

Leptogorgin B (2): colourless oil; $[\alpha]_{\mathrm{D}}^{22}+16\left(c 0.1, \mathrm{CHCl}_{3}\right)$; UV (EtOH) $\lambda_{\max }(\log \varepsilon) 196$ (3.23), 229 (3.07) nm; ECD $\left(c 3 \times 10^{-3} \mathrm{M}, \mathrm{EtOH}\right) \lambda_{\max }(\Delta \varepsilon) 197$ (2.90), 226 (1.41), 254 (-1.06), 336 (0.43) nm; ${ }^{1} \mathrm{H}$ and ${ }^{13} \mathrm{C}$ NMR data $\left(\mathrm{CDCl}_{3}\right)$ Table 1 ; HRESIMS $m / z 315.1571[\mathrm{M}+\mathrm{Na}]^{+}\left(\right.$calcd for $\mathrm{C}_{17} \mathrm{H}_{24} \mathrm{O}_{4} \mathrm{Na}$, 315.1567); HRESIMS $\mathrm{m} / z 291.1602[\mathrm{M}-\mathrm{H}]^{-}$(calcd for $\mathrm{C}_{17} \mathrm{H}_{23} \mathrm{O}_{4} 291.1602$ ).

Leptogorgin $C$ (3): colourless oil; ${ }^{1} \mathrm{H}$ and ${ }^{13} \mathrm{C}$ NMR data $\left(\mathrm{CDCl}_{3}\right)$ Table 1; HRESIMS $\mathrm{m} / \mathrm{z}$ $273.1463[\mathrm{M}+\mathrm{Na}]^{+}$(calcd for $\mathrm{C}_{15} \mathrm{H}_{22} \mathrm{O}_{3} \mathrm{Na}, 273.1461$ ); HRESIMS $m / z 249.1496[\mathrm{M}-\mathrm{H}]^{-}$(calcd for $\mathrm{C}_{15} \mathrm{H}_{21} \mathrm{O}_{3}$ 249.1496).

Leptogorgoid $A$ (4): colourless powder; $[\alpha]_{\mathrm{D}}^{22}+33\left(c 0.05, \mathrm{CHCl}_{3}\right) ;{ }^{1} \mathrm{H}$ and ${ }^{13} \mathrm{C}$ NMR data $\left(\mathrm{CDCl}_{3}\right)$ Table 1. HRESIMS $\mathrm{m} / \mathrm{z} 437.3021\left[\mathrm{M}+\mathrm{Na}^{+}\right.$(calcd for $\mathrm{C}_{27} \mathrm{H}_{42} \mathrm{O}_{3} \mathrm{Na}, 437.3026$ ); HRESIMS $\mathrm{m} / \mathrm{z}$ 413.3060 [M - H] $]^{-}$(calcd for $\mathrm{C}_{27} \mathrm{H}_{41} 0_{3}$ 413.3061).

MTPA esterification of $\mathbf{1}$. To a part of $\mathbf{1}\left(\begin{array}{lllllll}0.6 & \mathrm{mg}\end{array}\right)$ in $\operatorname{dry} \mathrm{C}_{5} \mathrm{H}_{5} \mathrm{~N} \quad\left(\begin{array}{ll}1 & \mu \mathrm{L}\end{array}\right)$, $R$-(-)- $\alpha$-metoxy- $\alpha$-trifluoromethylphenylacetyl chloride $(10 \mu \mathrm{L})$ was added. The mixture was stirred on one hour at room temperature.and evaporated in vacuo to give (S)-MTPA diester 1a. By the same procedure, $(R)$-MTPA diester $\mathbf{1} \mathbf{b}$ was prepared.

(S)-MTPA diester (1a): Select ${ }^{1} \mathrm{H}$ NMR data $\left(\mathrm{CDCl}_{3}\right)$ see Table S1. HRESIMS $m / z 707.25[\mathrm{M}+\mathrm{Na}]^{+}$ (calcd for $\mathrm{C}_{35} \mathrm{H}_{38} \mathrm{~F}_{6} \mathrm{O}_{7} \mathrm{Na}$, 707.25).

(R)-MTPA diester $(\mathbf{1 b})$ : Select ${ }^{1} \mathrm{H}$ NMR data $\left(\mathrm{CDCl}_{3}\right)$ see Table S1. HRESIMS $\mathrm{m} / z 707.25[\mathrm{M}+\mathrm{Na}]^{+}$ (calcd for $\mathrm{C}_{35} \mathrm{H}_{38} \mathrm{~F}_{6} \mathrm{O}_{7} \mathrm{Na}$, 707.25).

\subsection{Bioactivity Assay}

\subsubsection{Reagents}

The MTT reagent (Thiazolyl blue tetrazolium bromide) was purchased from Sigma (Taufkirchen, Germany).

\subsubsection{Cell Lines and Culture Conditions}

The human prostate cancer cells 22Rv1 and human prostate non-cancer cells PNT2 were purchased from ATCC. Cell lines were cultured according to the manufacturer's instructions in 10\% FBS/RPMI media (Invitrogen, Carlsbad, CA, USA) and handled as described in [29].

\subsubsection{In Vitro MTT-Based Drug Sensitivity Assay}

The in vitro cytotoxic activities of the isolated substances were evaluated by MTT assays. The assays were performed as described previously [30]. In brief, cells were seeded in 96-well 
plates $\left(6 \times 10^{3}\right.$ cells/well), incubated overnight, and treated with the tested compounds for $72 \mathrm{~h}$. Next, $10 \mu \mathrm{L} /$ well of MTT reagent was added and the plates were incubated for $2 \mathrm{~h}$. The media were aspirated and the plates were dried. The formed formazan crystals were dissolved in DMSO and the cell viability was measured using an Infinite F200PRO reader (TECAN, Männedorf, Switzerland). Results were calculated by the GraphPad Prism software v. 7.05 (GraphPad Prism software Inc., La Jolla, CA, USA) and are represented as the $\mathrm{IC}_{50}$ of the compounds against the control cells treated with the solvent alone.

\subsubsection{Colony Formation Assay}

Colony formation assay was performed as described before, with slight modifications [30]. Cells were treated with the drug for $48 \mathrm{~h}$; then, cells were trypsinized and the number of alive cells was counted with the trypan blue exclusion assay as described before [31]. One hundred viable cells were plated into each well of 6-well plates in complete drug-free media $(3 \mathrm{~mL} /$ well) and were incubated for 14 days. Then, the media were aspirated, surviving colonies were fixed with $100 \% \mathrm{MeOH}$, followed by washing with PBS and air-drying at RT. Next, cells were incubated with Giemsa staining solution for $25 \mathrm{~min}$ at RT, the staining solution was aspirated, and the wells were rinsed with $\mathrm{dH}_{2} \mathrm{O}$ and air-dried. The number of cell colonies was counted with the naked eye.

\section{Conclusions}

In summary, ${ }^{1} \mathrm{H}$ NMR-guided chemical investigation led to the isolation of three new humulane-type sesquiterpenoids and one new steroid. The structures of the new compounds were elucidated via analyses of their MS, NMR, and ECD spectroscopic data, as well as using the Mosher's esters analysis. These molecules represent the new humulenes possessing an oxygenation pattern which was significantly different from those found in plants, liverworts, and fungi. Leptogorgin A (1) exhibits a moderate cytotoxicity to human prostate cancer 22Rv1 cells.

Supplementary Materials: The following are available online at http://www.mdpi.com/1660-3397/18/6/310/s1. Copies of HRESIMS, 1D- and 2D-NMR spectra of 1-4.

Author Contributions: I.I.K. isolated the metabolites; T.N.M. elucidated structures; S.A.D. performed the bioactivity assays; A.I.K. performed the NMR spectra; R.S.P. performed the mass spectra; B.B.G. performed species identification of the gorgonian; G.v.A. assisted the results discussion; T.N.M., A.G.G. and V.A.S. wrote the paper, which was revised and approved by all the authors. All authors have read and agreed to the published version of the manuscript.

Funding: Isolation and establishment of chemical structures were partially supported by the RSF grant \#20-14-00040 (Russian Science Foundation).

Acknowledgments: The study was carried out on the equipment of the Collective Facilities Center "The Far Eastern Center for Structural Molecular Research (NMR/MS) PIBOC FEB RAS". We would like to thank Ms. Jessica Hauschild (University Medical Center Hamburg-Eppendorf) for technical support of the biological part of this research.

Conflicts of Interest: The authors declare no conflict of interest.

\section{References}

1. Carroll, A.R.; Copp, B.R.; Davis, R.A.; Keyzers, R.A.; Prinsep, M.R. Marine Natural Products. Nat. Prod. Rep. 2020, 37, 175-223. [CrossRef] [PubMed]

2. Dorta, E.; Diaz-Marrero, A.R.; Brito, I.; Cueto, M.; D'Croz, L.; Darias, J. The oxidation profile at C-18 of furanocembranolides may provide a taxonomical marker for several genera of octocorals. Tetrahedron 2007, 63, 9057-9062. [CrossRef]

3. Ortega, M.J.; Zubia, E.; Sanchez, M.C.; Carballo, J.L. Cembrane diterpenes from the gorgonian Leptogorgia laxa. J. Nat. Prod. 2008, 71, 1637-1639. [CrossRef] [PubMed]

4. Gerhart, D.J.; Coll, J.C. Pukalide, a widely distributed octocoral diterpenoid, includes vomiting in fish. J. Chem. Ecol. 1993, 19, 2697-2704. [CrossRef] [PubMed] 
5. Gutierrez, M.; Capson, T.L.; Guzman, C.M.; Gonzalez, J.; Ortega-Barria, E.; Quinoa, E.; Riguera, R. Leptolide, a new furanocembranolide diterpene from Leptogorgia alba. J. Nat. Prod. 2005, 68, 614-616. [CrossRef]

6. Diaz-Marrero, A.R.; Porras, G.; Gueto, M.; D’Croz, L.; Lorenzo, M.; San-Martin, A.; Darias, J. Leptogorgolide, a biogenetically interesting 1,4-diketo-cembranoid that reinforcesthe oxidation profile of C-18 as taxonomical marker for octocorals. Tetrahedron 2009, 65, 6029-6033. [CrossRef]

7. Gallardo, A.B.; Diaz-Marrero, A.R.; de la Rosa, J.M.; D'Croz, L.; Perdomo, G.; Cozar-Castello, I.; Darias, J.; Gueto, M. Chloro-furanocembranolides from Leptogorgia sp. improve pancreatic beta-cell proliferation. Mar. Drugs 2018, 16, 49. [CrossRef]

8. Cimino, G.; De Rosa, S.; De Stefano, S.; Scognamiglio, G.; Sodano, G. Cholest-4,14-dien-20k-diol-3,16-dione, a novel polyoxygenated marine steroid which easily loses the side chain. Tetrahedron Lett. 1981, 22, 3013-3016. [CrossRef]

9. Cimino, G.; De Rosa, S.; De Stefano, S.; Sodano, G. C-18 Hydroxy steroids from the Mediterranean gorgonian Leptogorgia sarmentosa. Experientia 1984, 40, 246-248. [CrossRef]

10. Benvegnu, R.; Cimino, G.; De Rosa, S.; De Stefano, S. Guggulsterol-like steroids from the Mediterranean gorgonian Leptogorgia sarmentosa. Experientia 1982, 38, 1443-1444. [CrossRef]

11. Garrido, L.; Zubia, E.; Ortega, M.J.; Salva, J. Isolation and structure elucidation of new cytotoxic steroids from the gorgonian Leptogorgia sarmentosa. Steroids 2000, 65, 85-88. [CrossRef]

12. Moritz, M.I.G.; Marostica, L.L.; Bianco, E.M.; Almeida, M.T.R.; Carraro, J.L.; Cabrera, G.M.; Palermo, J.A.; Simoes, C.M.O.; Schenkel, E.P. Polyoxygenated steroids from the octocoral Leptogorgia punicea and in vitro evaluation of their cytotoxic activity. Mar. Drags 2014, 12, 5864-5880. [CrossRef] [PubMed]

13. Keyzers, R.A.; Gray, C.A.; Schleyer, M.H.; Whibley, C.E.; Hendricks, D.T.; Davies-Coleman, M.T. Malonganenones A-C, novel tetraprenylated alkaloids from the Mozambique gorgonian Leptogorgia gilchristi. Tetrahedron 2006, 62, 2200-2206. [CrossRef]

14. Miralles, J.; Barnathan, G.; Galonnier, R.; Sall, T.; Samb, A.; Gaydou, E.M.; Kornprobst, J.M. New branched-chain fatty acids from the Senegalese gorgonian Leptogorgia piccola (white and yellow morphs). Lipids 1995, 30, 459-466. [CrossRef] [PubMed]

15. Targett, N.M.; Bishop, S.S.; McConnell, O.J.; Yoder, J.A. Antifouling agents against the benthic marine diatom, Navicula salinicola. Homarine from the gorgonians Leptogorgia virgulata and L. setacea and analogs. J. Chem. Ecol. 1983, 9, 817-829. [CrossRef]

16. Kingsley, R.J.; Corcoran, M.L.; Krider, K.L.; Kriechbaum, K.L. Thyroxine and vitamin D in the gorgonian Leptogorgia virgulata. Comp. Biochem. Physiol. 2001, 129, 897-907. [CrossRef]

17. Otto, A.; Wilde, V. Sesqui- di-, and triterpemoids as chemosystematic markers in extant conifers. A review. Bot. Rev. 2001, 67, 141-238. [CrossRef]

18. Schifrin, A.; Litzenburger, M.; Ringle, M.; Ly, T.T.B.; Bernhardt, R. New sesqiterpene oxidations with CYP260A1 and CYP264B1 from Sorangium cellulosum Soce56. ChemBioChem 2015, 16, 2624-2632. [CrossRef]

19. Nagashima, F.; Tabuchi, Y.; Ito, T.; Harinantenaia, L.; Asakawa, Y. Terpenoids, Flavonoids, and Acetogenins from some Malagasy plants. Nat. Prod. Commmun. 2016, 11, 153-157. [CrossRef]

20. Toyota, M.; Omatsu, J.; Braggins, J.; Asakawa, Y. New humulane-type sesquiterpenes from the liverworts Tylimamthus tenellus and Marchantia emarginata subsp tosana. Chem. Pharm. Bull. 2004, 52, 481-484. [CrossRef]

21. Wang, J.F.; He, W.J.; Kong, F.D.; Tian, J.P.; Wang, P.; Zhou, X.J.; Liu, Y.H. Ochramecenes A-I, humulane-derived sesquiterpenoids from the Antharctic fungus Aspergillus ochraceopetaliformis. J. Nat. Prod. 2017, 80, 1725-1733. [CrossRef] [PubMed]

22. Chen, H.P.; Liu, J. Secondary metaboilites from higher fungi. Prog. Chem. Org. Nat. Prod. 2017, 106, 1-201. [CrossRef] [PubMed]

23. Wu, Z.; Liu, D.; Proksch, P.; Guo, P.; Lin, W. Punctaporonins H-M: Caryophyllene-type sesquiterpenoids from the sponge-associated fungus Hansfordia sinuosae. Mar. Drugs 2014, 12, 3904-3916. [CrossRef] [PubMed]

24. Lu, S.Q.; Li, X.W.; Li, S.W.; Cui, Z.; Guo, Y.W.; Hun, G.Y. Sinuhirtins A and B, two uncommon norhumulane-type terpenoids from the South China Sea soft coral Sinularia hirta. Tetrahedron Lett. 2019, 60, 151308. [CrossRef]

25. Chen, S.P.; Su, J.H.; Yeh, H.C.; Ahmed, A.F.; Dai, C.F.; Wu, Y.C.; Sheu, J.H. Novel norhumulene and xeniaphyllane-derived terpenoids from a Formosan Soft Coral Sinularia gibberosa. Chem. Pharm. Bull. 2009, 57, 162-166. [CrossRef] 
26. Zhang, R.; Feng, X.; Su, G.; Mu, Z.; Zhang, H.; Zhao, Y.; Jiao, S.; Cao, L.; Chen, S.; Tu, P.; et al. Bioactive sesquiterpenoids from the peeled stems of Syringa pinnatifolia. J. Nat. Prod. 2018, 81, 1711-1720. [CrossRef]

27. Yu, F.; Okomoto, S.; Harada, H.; Yamasaki, K.; Misawa, N.; Utsumi, R. Zingiber zerumbet CYP71BA1 catalyses the conversion of $\alpha$-humulene to 8-hydroxy- $\alpha$-humulene. Cell. Mol. Life Sci. 2011, 68, 1033-1040. [CrossRef]

28. Kirana, C.; Mcintosh, G.H.; Record, I.R.; Jones, G.P. Antitumor activity of extract of Zinger aromaticum and its bioactive sesquiterpenoid zerumbone. Nutr. Cancer 2003, 45, 218-225. [CrossRef]

29. Dyshlovoy, S.A.; Menchinskaya, E.S.; Venz, S.; Rast, S.; Amann, K.; Hauschild, J.; Otte, K.; Kalinin, V.I.; Silchenko, A.S.; Avilov, S.A.; et al. The marine triterpene glycoside frondoside A exhibits activity in vitro and in vivo in prostate cancer. Int. J. Cancer 2016, 138, 2450-2465. [CrossRef]

30. Dyshlovoy, S.A.; Venz, S.; Hauschild, J.; Tabakmakher, K.M.; Otte, K.; Madanchi, R.; Walther, R.; Guzii, A.G.; Makarieva, T.N.; Shubina, L.K.; et al. Antimigrating activity of marine alkaloid monanchocidin A, proteome-based discovery and confirmation. Proteomics 2016, 16, 1590-1603. [CrossRef]

31. Dyshlovoy, S.A.; Hauschild, J.; Amann, K.; Tabakmakher, K.M.; Venz, S.; Walther, R.; Guzii, A.G.; Makarieva, T.N.; Shubina, L.K.; Fedorov, S.N.; et al. Marine alkaloid Monanchocidin A overcomes drug resistance by induction of autophagy and lysosomal membrane permeabilization. Oncotarget 2015, 6, 17328-17341. [CrossRef] [PubMed]

(C) 2020 by the authors. Licensee MDPI, Basel, Switzerland. This article is an open access article distributed under the terms and conditions of the Creative Commons Attribution (CC BY) license (http://creativecommons.org/licenses/by/4.0/). 